\title{
Zooarchaeological Implications for Prehistoric Distributions of Seabirds along the Norwegian Coast
}

\author{
W.A. MONTEVECCHI ${ }^{1}$ and A.K. HUFTHAMMER ${ }^{2}$
}

(Received 3 November 1988; accepted in revised form 5 December 1989)

\begin{abstract}
Investigation of the temporal and spatial distributions of zooarchaeological material can aid in understanding of the palaeoecology of nonhuman and human species. Northern gannets (Sula bassanas) and northern fulmars (Fulmarus glacialis) were first documented to breed in Norway during the present century. Skeletal remains of gannets and fulmars uncovered at Norwegian archaeological sites have been dated from approximately 7000 to 800 B.P. and from about 30000 to 400 B.P. respectively. The modal occurrence of gannet specimens was $6000-5000$ B.P. and that of fulmar material was 2000-1000 B.P., suggesting that in the postglacial period most gannets occurred in Norwegian waters earlier than did most fulmars. Recovered fulmar bones greatly outnumber those of gannets, a pattern consistent with relative abundances in Norwegian waters today, but one that might also reflect differential accessibility and/or prey preferences of previous coastal inhabitants. Proportionally more of the fulmar material was uncovered at proportionally more sites in North Norway, findings consistent with current species' distributions and with speculation of similar oceanographic conditions in previous millenia.
\end{abstract}

Key words: climatology, northern fulmar (Fulmarus glacialis), northern gannet (Sula bassanas), Norway, palaeoecology, seabirds, zooarchaeology

RESSUMÉ. La recherche sur la distribution temporelle et spatiale de matériau zooarchéologique peut aider à comprendre la paléoécologie des espèces non humaines et humaines. On a établi pour la première fois au cours de ce siècle que le fou de Bassan (Sula bassanas) et le fulmar boréal (Fulmarus glacialis) se reproduisaient déjà en Norvège à une époque reculée. On a en effet découvert dans des sites archéologiques de Norvège, des restes de squelettes de fous et de fulmars datant respectivement d'environ 7000 à 800 ans avant notre ère et 30000 à 400 ans avant notre ère. Parmi les spécimens de fous, ceux datant de 6000 à 5000 avant notre ère sont les plus fréquents et parmi les restes de fulmars, ceux datant de 2000 à 1000 avant notre ère sont les plus fréquents. Cette observation donne à penser qu'au cours de la période post-glaciaire, la fréquence maximale du fou dans les eaux norvégiennes a été antérieure à celle du fulmar. La quantité d'os de fulmars retrouvée dépasse largement celle d'os de fous, ce qui est en accord avec les quantités relatives actuelles d'oiseaux dans les mers norvégiennes, tout en pouvant aussi refléter l'accessibilité différentielle et/ou une préférence pour certaines proies qu'avaient les habitants précédents de la région côtière. Proportionnellement plus de restes de fulmars ont été découverts sur un nombre proportionnellement plus important de sites dans le nord de la Norvège, résultats qui correspondent aux distributions actuelles $\mathrm{d}^{\prime}$ espèces et à la théorie suivant laquelle la situation océanographique était la même dans les millénaires qui ont précédé.

Mots clés: climatologie, fulmar boréal (Fulmarus glacialis), fou de Bassan (Sula bassanas), Norvège, paléoécologie, oiseaux marins, zooarchéologie

Traduit pour le journal par Nésida Loyer.

\section{INTRODUCTION}

Zooarchaeological analyses can aid in the investigation and understanding of palaeoecology (Yesner, 1976; Schledermann, 1980; Hasegawa and DeGange, 1982; Montevecchi and Tuck, 1987). Faunal remains recovered at archaeological excavations can often provide information about species' distributions and abundances and their temporal fluctuations during prehistoric periods (Wintemberg, 1919; Friedman, 1934; Hall, 1969; Walker and Craig, 1979; Jordan and Olson, 1982; Meldgaard, 1988). Such information must be used cautiously, as artifacts were often transported long distances from points of origin via trading or transfer of material among neighboring or interacting groups (Lucas, 1903; Gilbert et al., 1981), and faunal remains may also reflect differences in prey vulnerability and/or changes in the preferences, technologies or economies of former human inhabitants. Within theselimitations, broad comparisons of significant zooarchaeological patterns with biological, palaeoecological and palaeoclimatological information can be both revealing and heuristic.

During historic times, northern gannets (Sula bassana) were first documented breeding in Norway in 1947, when they were reported nesting at Runde (Valeur, 1947). Northern fulmars (Fulmarus glacialis) first nested in Norway at Runde early in the present century, and by 1947 the breeding population was considered to be 350 pairs (Valeur, 1947; Barrett and Vader, 1984). Barrett and Vader (1984) indicate that archaeological evidence suggests that gannets and possibly fulmars bred in former times in North Norway. If so, it might be expected that a preponderance of the remains of these species would occur at northern archaeological sites. If prehistoric distributions were consistent with historical ones (Fisher, 1952; Nelson, 1978), one would expect to find most fulmar specimens in the north and most gannet specimens in the south. To explore these possibilities and to gain better understanding of former occurrences of seabirds along the Norwegian coast, the spatial and temporal distributions of bones of these and other avian species recovered from archaeological sites are statistically compared. Findings are considered in terms of prehistoric climatological conditions.

\section{MATERIALS AND METHODS}

The Zoological Museum at the University of Bergen is the national repository for nonhuman bones uncovered at Norwegian archaeological sites. Bone material, museum catalogues, and published and unpublished reports were searched for avian specimens. Bones were dated whenever possible and were grouped by date and county. References regarding dating of material, which is based on archaeological evidence or radiocarbon measurements, can be found in Hufthammer (1982). Undated material is considered prehistoric, i.e., usually $\geq 1000$ B.P.

\footnotetext{
'Departments of Psychology and Biology and Ocean Sciences Centre, Memorial University of Newfoundland, St. John's, Newfoundland, Canada A1B 3X9

${ }^{2}$ Department of Osteology, Zoological Museum, University of Bergen, N-5007 Bergen, Norway

(C) The Arctic Institute of North America
} 
Bones of fulmars, gannets and all other avian species combined were statistically analyzed and compared for significant patterns among spatial and temporal distributions. For analytical purposes, counties from and including Nordland northwards were grouped as northern Norway, while those from and including Nord Trøndelag southwards were grouped as southern Norway. For temporal analyses, bones were assigned to these categories: $<1,1-2,3-4,5-6,7-8$ and (for the fulmar data) $>8$ millenia B.P. When gannets and fulmars were compared with one another and with other avian species, the oldest bones were classified as $>7$ millenia B.P. Chi-square $\left(x^{2}\right)$ tests (Siegel, 1956) were used to assess spatial and temporal distributions. Following tests of normality of data distributions, one-way analyses of variance and Mann-Whitney $U$ tests were used as appropriate to compare the datings of archaeological sites (at which avian bones have been recovered) in northern and southern Norway. Statistical significance is taken as $\mathrm{P}<0.05$.

\section{RESULTS}

More than 120 gannet bones have been uncovered at 26 archaeological sites along most of the Norwegian coast (Table 1; Fig. 1). These specimens are unevenly distributed among counties $\left(x_{7}^{2}=185.05, P<0.001\right)$. Most have been recovered in Møre and Romsdal $(37 \%, 46 / 124)$ in southern Norway and in Nordland (34\%, 42/124), and about $9 \%(11 / 124)$ have come from Rogaland. Gannet specimens were recovered at 6 sites in Møre and Romsdal, 5 sites in Nordland and 4 sites in Finnmark. Gannet bones constituted significantly different proportions of the avian bones recovered in the 8 counties in which gannet bones were recovered $\left(x_{7}^{2}=112.3, P<0.001\right)$. Although most of the gannet bones have been recovered in More and Romsdal and in Nordland, gannet bones make up very small percentages of the total avian material collected from these counties, i.e., 0.5 and $1.4 \%$ respectively. In other counties where fewer gannet bones have been recovered, they make up much larger percentages of the avian material (Nord Trøndelag - 12.5\%; Rogaland - 4.5\%; Sør - Trøndelag $-4.5 \%$; Sogn and Fjordane $-4.2 \%$ ). Some individual sites also have high percentages of gannet material. Approximately $20 \%$ of the avian material identified to species at Aakvik, Donnes, was from gannets. At Kaupang, gannet bones constituted $10 \%$ of the avian material. These percentages are even more striking in view of the high number of species recorded at each of these sites.

Almost 600 fulmar bones have been recovered from 28 Norwegian archaeological sites (Table 2; Fig. 2). Like the gannet bones, the fulmar remains are unevenly distributed among counties $\left(x_{7}^{2}=483.6, \mathrm{P}<0.001\right)$. Ninety-two percent $(549 / 598)$ of the fulmar specimens were recovered in Finnmark and Nordland; 6\% (38/598) were found in More and Romsdal. Fulmar bones have been uncovered at 12 sites in Finnmark, 5 sites in Nordland and 4 sites in Møre and Romsdal. Fulmar specimens made up significantly different proportions of the avian bones in the 8 counties where they were recovered $\left(x_{7}^{2}\right.$ $=437.16, \mathrm{P}<0.001)$ and constituted the highest percentages of avian bones in those counties where the most fulmar bones were collected: $6.2 \%(216 / 3507)$ at Nordland and $4.5 \%(333 /$ 7371) at Finnmark (Table 2; Fig. 2). At the Toften II site in Andøy fulmar accounted for 59\% (134/224) of the avian bones, at Bleik in Andøy 11\% (66/587) of the avian bones
TABLE 1. Gannet material recovered from Norwegian archaeological sites (see Fig. 1 for site locations)

\begin{tabular}{|c|c|c|c|c|}
\hline & Site & Kommune & Dated (B.P.) & $\begin{array}{l}\text { Number of } \\
\text { fragments }^{\mathrm{a}}\end{array}$ \\
\hline $\begin{array}{l}1 \\
2\end{array}$ & $\begin{array}{l}\text { Rogaland (R) } \\
\text { Gaasehilleren } \\
\text { Vistehulen } \\
\text { County summary }\end{array}$ & $\begin{array}{l}\text { Sola } \\
\text { Randaberg }\end{array}$ & $\begin{array}{l}\sim 3000 \\
8000-6100 \\
8000-\sim 3000\end{array}$ & $\begin{array}{l}1(6) 2 \\
10(237) 29 \\
11(243)\end{array}$ \\
\hline $\begin{array}{l}3 \\
4\end{array}$ & $\begin{array}{l}\text { Hordaland }(\mathrm{H}) \\
\text { Ruskeneset } \\
\text { Bryggen } \\
\text { County summary }\end{array}$ & $\begin{array}{l}\text { Bergen } \\
\text { Bergen }\end{array}$ & $\begin{array}{l}3100-2600 \\
800-600 \\
3100-600\end{array}$ & $\begin{array}{l}2(31) 16 \\
3(221) 27 \\
5(252)\end{array}$ \\
\hline $\begin{array}{l}5 \\
6 \\
7\end{array}$ & $\begin{array}{l}\text { Sogn Og Fjordane (SF) } \\
\text { Grønehelleren } \\
\text { Baatekletten } \\
\text { Ovn. Lillebatalden } \\
\text { Country summary }\end{array}$ & $\begin{array}{l}\text { Solund } \\
\text { Askvoll } \\
\text { Flora }\end{array}$ & $\begin{array}{l}5500-4100 \\
\text { age unknown } \\
\text { age unknown } \\
5500-4100\end{array}$ & $\begin{array}{l}4(109) 17 \\
1(1) 1 \\
1(33) 18 \\
6(143)\end{array}$ \\
\hline $\begin{array}{r}8 \\
9 \\
10 \\
11 \\
12 \\
13\end{array}$ & $\begin{array}{l}\text { Møre Og Romsdal (MR) } \\
\text { Dollsteinhola } \\
\text { Skylehammeren } \\
\text { Kaupang } \\
\text { Skjonghelleren } \\
\text { Sauehelleren } \\
\text { Møislaatten } \\
\text { County summary }\end{array}$ & $\begin{array}{l}\text { Sandsøy } \\
\text { Aalesund } \\
\text { Aalesund } \\
\text { Giske } \\
\text { Midsund } \\
\text { Tustna }\end{array}$ & $\begin{array}{l}5600-3500 \\
1800-1400 \\
900-800 \\
\sim 2500 \\
1800-1400 \\
\text { age unknown } \\
5600-800\end{array}$ & $\begin{array}{l}29(8068) 124 \\
1(5) 4 \\
10(100) 23 \\
1(38) 20 \\
\sim 4(\sim 60) 22 \\
1(6) 4 \\
46(8277)\end{array}$ \\
\hline $\begin{array}{l}14 \\
15\end{array}$ & $\begin{array}{l}\text { Sør-Trøndelag (ST) } \\
\text { Hestneshulen } \\
\text { Ramsøy } \\
\text { County summary }\end{array}$ & $\begin{array}{l}\text { Hitra } \\
\text { Osen }\end{array}$ & $\begin{array}{l}2500-1400 \\
2500-2000 \\
2500-1400\end{array}$ & $\begin{array}{l}1(32) 18 \\
4(79) 21 \\
5(111)\end{array}$ \\
\hline $\begin{array}{l}16 \\
17\end{array}$ & $\begin{array}{l}\text { Nord Trøndelag (NT) } \\
\text { Sandhelleren } \\
\text { Kuhelleren, Halmøy } \\
\text { County summary }\end{array}$ & $\begin{array}{l}\text { Flatanger } \\
\text { Flatanger }\end{array}$ & $\begin{array}{l}\text { age unknown } \\
>3500 \\
>3500\end{array}$ & $\begin{array}{l}1(12) 9 \\
1(4) 4 \\
2(16)\end{array}$ \\
\hline $\begin{array}{l}18 \\
19 \\
20 \\
21 \\
22\end{array}$ & $\begin{array}{l}\text { Nordland (N) } \\
\text { Langaasen } \\
\text { Aakvik, Dønnes } \\
\text { Kirkehelleren } \\
\text { Storbaathelleren } \\
\text { Toften II } \\
\text { County summary }\end{array}$ & $\begin{array}{l}\text { Vega } \\
\text { Herøy } \\
\text { Traena } \\
\text { Flakstad } \\
\text { Andøy }\end{array}$ & $\begin{array}{l}2900-2700 \\
5000-3500 \\
2500-2000 \\
5300-4600 \\
-1400-1200 \\
5000-\sim 1400\end{array}$ & $\begin{array}{l}1(8) 3 \\
10(59) 12 \\
9(870) 33 \\
21(1816) 38 \\
1(228) 15 \\
42(2981)\end{array}$ \\
\hline $\begin{array}{l}23 \\
24 \\
25 \\
26\end{array}$ & $\begin{array}{l}\text { Finnmark (F) } \\
\text { Vardøhus } \\
\text { Mortensnes } \\
\text { Nyelv } \\
\text { Kjø-øya } \\
\text { County summary }\end{array}$ & $\begin{array}{l}\text { Vardø } \\
\text { Nesseby } \\
\text { Nesseby } \\
\text { Sør-Varanger }\end{array}$ & $\begin{array}{l}2700-2400 \\
1250-850 \\
4600-4100 \\
2700-2400 \\
4600-850\end{array}$ & $\begin{array}{l}2(727) 13 \\
1(103) 13 \\
3(663) 21 \\
1(164) 20 \\
7(1657)\end{array}$ \\
\hline
\end{tabular}

Summary of sites where

gannet bones were recovered

$8000-600$

$124(13680)$

aFirst number indicates gannet bones; next is total number of avian bones identified to species in parenthesis; last number indicates total avian species represented at site. Domestic fowl are excluded from tabulation.

were fulmar, and at Vardøhus fulmar specimens made up $10 \%(74 / 727)$ of the avian total.

The bones of gannets and fulmars were collected at 26 and 28 coastal sites respectively and in 8 counties each. Gannet bones were uncovered at 15 sites where no fulmar bones were found. Fulmar bones were uncovered in 2 counties (Oslo; Troms) where gannet bones were not, and conversely, gannet bones were collected in 2 counties (Sogn and Fjordane; Nord Trøndelag) where fulmar bones were not. In comparison to each other, proportionally more fulmar bones were found at proportionally more sites in northern Norway (Table 3 ). 


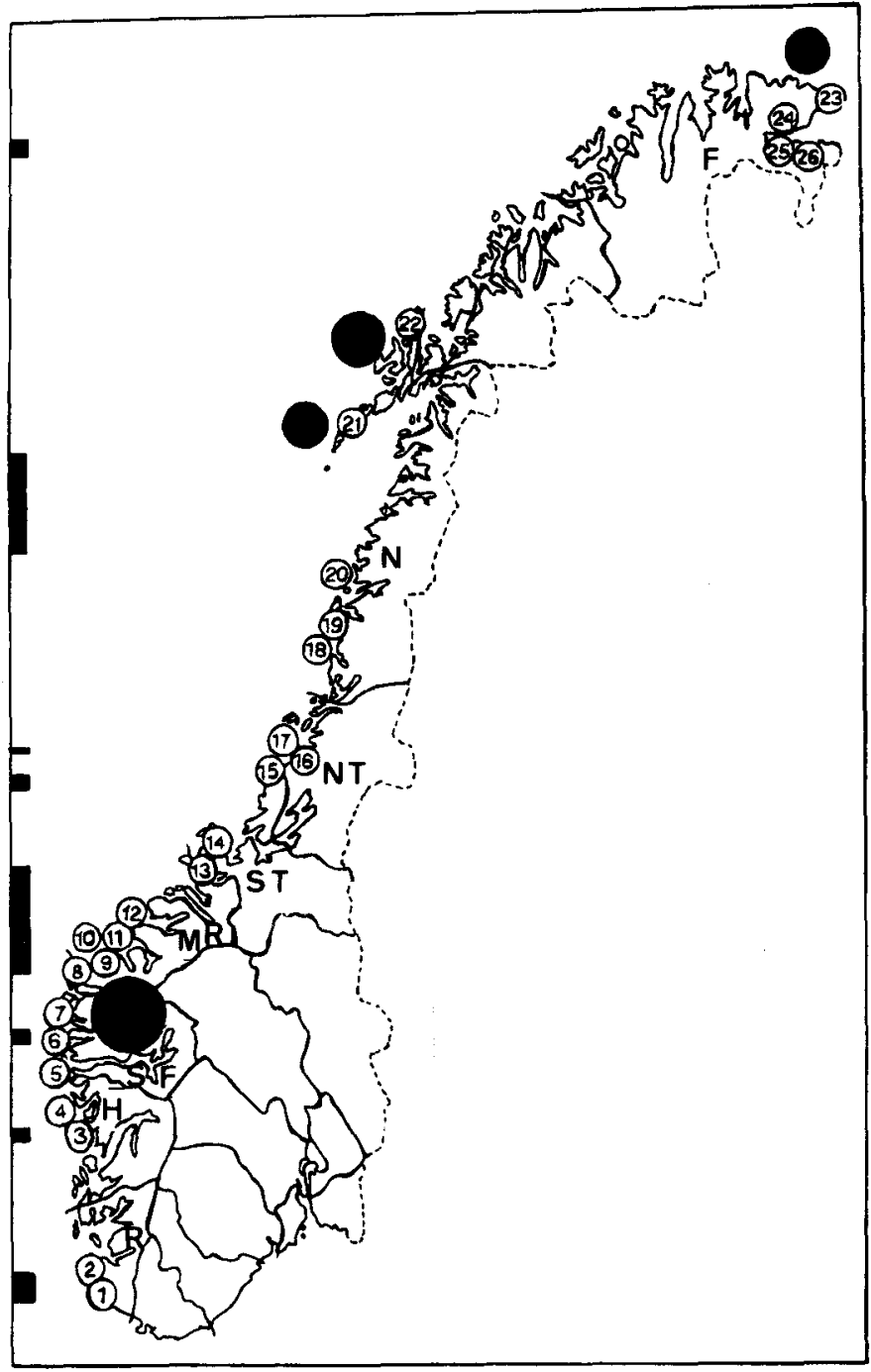

FIG. 1. Norwegian archaeological sites at which gannet bones have been recovered. Numbers and letters correspond to locations and counties given in Table 1. Bars along border of figure are proportional to the percentages of bones uncovered at adjacent counties on map. Circles are proportional to total breeding population at each of four gannet colonies as of 1985 (Montevecchi et al., 1987); from south to north gannetries are located at Runde, Hovsflesa, Skarvklakken and Syltefjord.

In an analysis of all Norwegian archaeological sites where avian bones have been recovered, there was no statistically significant difference in the proportions of sites in the northern and southern parts of the country from which fulmar and/or gannet bones and other avian species were recovered. Fulmar recoveries alone, however, were made at proportionally more northern sites than were bones of avian species other than fulmars and gannets $\left(x_{1}^{2}=6.14, P<0.02\right)$. Gannet bones, in turn, were recovered at northern and southern sites in proportions that were not significantly different from those of other avian species. More fulmar bones were recovered at northern sites than were other avian bones $\left(x_{1}^{2}=\right.$ 764.7, $\mathrm{P}<0.001$ ), whereas gannet bones were not.

Gannet bones were recovered at sites dated from approximately 7000 to 800 B.P., whereas the dates associated with fulmar bones ranged from about 30000 to 400 B.P. (Tables 1
TABLE 2. Fulmar material recovered from Norwegian archaeological sites (see Fig. 2 for site locations)

\begin{tabular}{|c|c|c|c|c|}
\hline & Site & Kommune & Date (B.P.) ${ }^{\mathbf{a}}$ & $\begin{array}{l}\text { Number of } \\
\text { fragments }\end{array}$ \\
\hline 1 & $\begin{array}{l}\text { Oslo }(O) \\
\text { Mindets tomt } \\
\text { County summary }\end{array}$ & Oslo & $\begin{array}{l}850-800 \\
850-800\end{array}$ & $\begin{array}{l}1(98) 18 \\
1(98) 18\end{array}$ \\
\hline $\begin{array}{l}2 \\
3\end{array}$ & $\begin{array}{l}\text { Rogaland (R) } \\
\text { Slettabø, Ogna } \\
\text { Vistehulen } \\
\text { County summary }\end{array}$ & $\begin{array}{l}\text { Eigersund } \\
\text { Randaberg }\end{array}$ & $\begin{array}{l}4000-3700 \\
8000-6100 \\
8000-3700\end{array}$ & $\begin{array}{l}1(11) 7 \\
3(237) 29 \\
4(248)\end{array}$ \\
\hline 4 & $\begin{array}{l}\text { Hordaland (H) } \\
\text { Blomvaag } \\
\text { County summary }\end{array}$ & Øygarden & $\begin{array}{l}12700-12100 \\
12700-12100\end{array}$ & $\begin{array}{l}1(116) 16 \\
1(116) 16\end{array}$ \\
\hline $\begin{array}{l}5 \\
6 \\
7 \\
7\end{array}$ & $\begin{array}{l}\text { Møre Og Romsdal (MR) } \\
\text { Dollsteinhola } \\
\text { Kaupang } \\
\text { Skjonghelleren } \\
\text { Skjonghelleren } \\
\text { County summary }\end{array}$ & $\begin{array}{l}\text { Sandøy } \\
\text { Aalesund } \\
\text { Giske } \\
\text { Giske }\end{array}$ & $\begin{array}{l}5600-3500 \\
900-800 \\
\sim 30000 \\
\sim 2500 \\
\sim 30000-800\end{array}$ & $\begin{array}{l}31(8068) 124 \\
2(100) 23 \\
2(1863) 14 \\
3(38) 20 \\
38(10069)\end{array}$ \\
\hline $\begin{array}{l}8 \\
9\end{array}$ & $\begin{array}{l}\text { Sør-Trøndelag (ST) } \\
\text { Televerkstomten } \\
\text { Ramsøy } \\
\text { County summary }\end{array}$ & $\begin{array}{l}\text { Trondheim } \\
\text { Osen }\end{array}$ & $\begin{array}{l}1000-500 \\
2500-2000 \\
2500-500\end{array}$ & $\begin{array}{l}1(803) 51 \\
1(79) 21 \\
2(882)\end{array}$ \\
\hline $\begin{array}{l}10 \\
11 \\
12 \\
13 \\
14\end{array}$ & $\begin{array}{l}\text { Nordland (N) } \\
\text { Kirkehelleren } \\
\text { Storbaathelleren } \\
\text { Toften II } \\
\text { Dverberg } \\
\text { Bleik } \\
\text { County summary }\end{array}$ & $\begin{array}{l}\text { Traena } \\
\text { Flakstad } \\
\text { Andøy } \\
\text { Andøy } \\
\text { Andøy }\end{array}$ & $\begin{array}{l}2500-2000 \\
5300-4600 \\
1600-1400 \\
650 \text { or } 450-250 \\
2000-1300 \\
5300-350\end{array}$ & $\begin{array}{l}4(870) 33 \\
9(1816) 38 \\
134(228) 15 \\
3(6) 4 \\
66(587) 11 \\
216(3507)\end{array}$ \\
\hline $\begin{array}{l}15 \\
16 \\
17\end{array}$ & $\begin{array}{l}\text { Troms }(\mathrm{T}) \\
\text { Gaardshaugen } \\
\text { Nordskar } \\
\text { Vanna } \\
\text { County summary }\end{array}$ & $\begin{array}{l}\text { Helgøy } \\
\text { Karlsøy } \\
\text { Karlsøy }\end{array}$ & $\begin{array}{l}\sim 400 \\
<800 \\
\sim 700 \\
<800-400\end{array}$ & $\begin{array}{l}1(326) 26 \\
1(45) 10 \\
1(20) 5 \\
3(391)\end{array}$ \\
\hline $\begin{array}{l}18 \\
19 \\
20 \\
21 \\
22 \\
23 \\
24 \\
25 \\
25 \\
26 \\
27 \\
28\end{array}$ & $\begin{array}{l}\text { Finnmark (F) } \\
\text { Iversfjord } \\
\text { Vardøhus } \\
\text { Mortensnes } \\
\text { Angsnes } \\
\text { Karlebotn } \\
\text { Gropbakkengen } \\
\text { Gressbakken } \\
\text { Nyelv } \\
\text { Nyelv } \\
\text { Kjø-øya } \\
\text { Mestersanden } \\
\text { Makkhola, Kjelmøy } \\
\text { County summary }\end{array}$ & $\begin{array}{l}\text { Gamvik } \\
\text { Vardø } \\
\text { Nesseby } \\
\text { Nesseby } \\
\text { Nesseby } \\
\text { Nesseby } \\
\text { Nesseby } \\
\text { Nesseby } \\
\text { Nesseby } \\
\text { Sør-Varanger } \\
\text { Sør-Varanger } \\
\text { Sør-Varanger }\end{array}$ & $\begin{array}{l}\sim 4500 \\
\text { age unknown } \\
700-500 \\
1800-1500 \\
5300-4800 \\
6300-4500 \\
4400-3900 \\
4600-4100 \\
4600-4100 \\
2700-2400 \\
2700-2000 \\
2700-2400 \\
6300-500\end{array}$ & $\begin{array}{l}7(250) 27 \\
74(727) 13 \\
1(17) 8 \\
1(9) 4 \\
14(462) 13 \\
3(21) 9 \\
98(3905) 32 \\
35(817) 15 \\
26(663) 21 \\
32(164) 20 \\
41(270) 20 \\
1(66) 14 \\
333(7371)\end{array}$ \\
\hline & $\begin{array}{l}\text { nmary for sites where } \\
\text { mar bones were recovered }\end{array}$ & & $-30000-350$ & $598(22782)$ \\
\hline
\end{tabular}

aata from Simonsen (1974-82), Solberg (1976), Skjølsvold (1977), Helskog (1980), Hufthammer (1982), Larsen et al. (1987), Lie (1990).

${ }^{b}$ First number indicates fulmar bones; next is total number of avian bones identified to species in parentheses; last number indicates total avian species represented at site. Domestic fowl are excluded from tabulations.

and 2). Both gannet and fulmar bones were unevenly distributed with respect to the millenia from which these materials were collected (for gannets $x_{4}^{2}=53.39, p<0.001$; for fulmars $x_{5}^{2}$ $=639.5, P<0.001$ ), and temporal distributions of the bones of the two species were significantly different from one another 


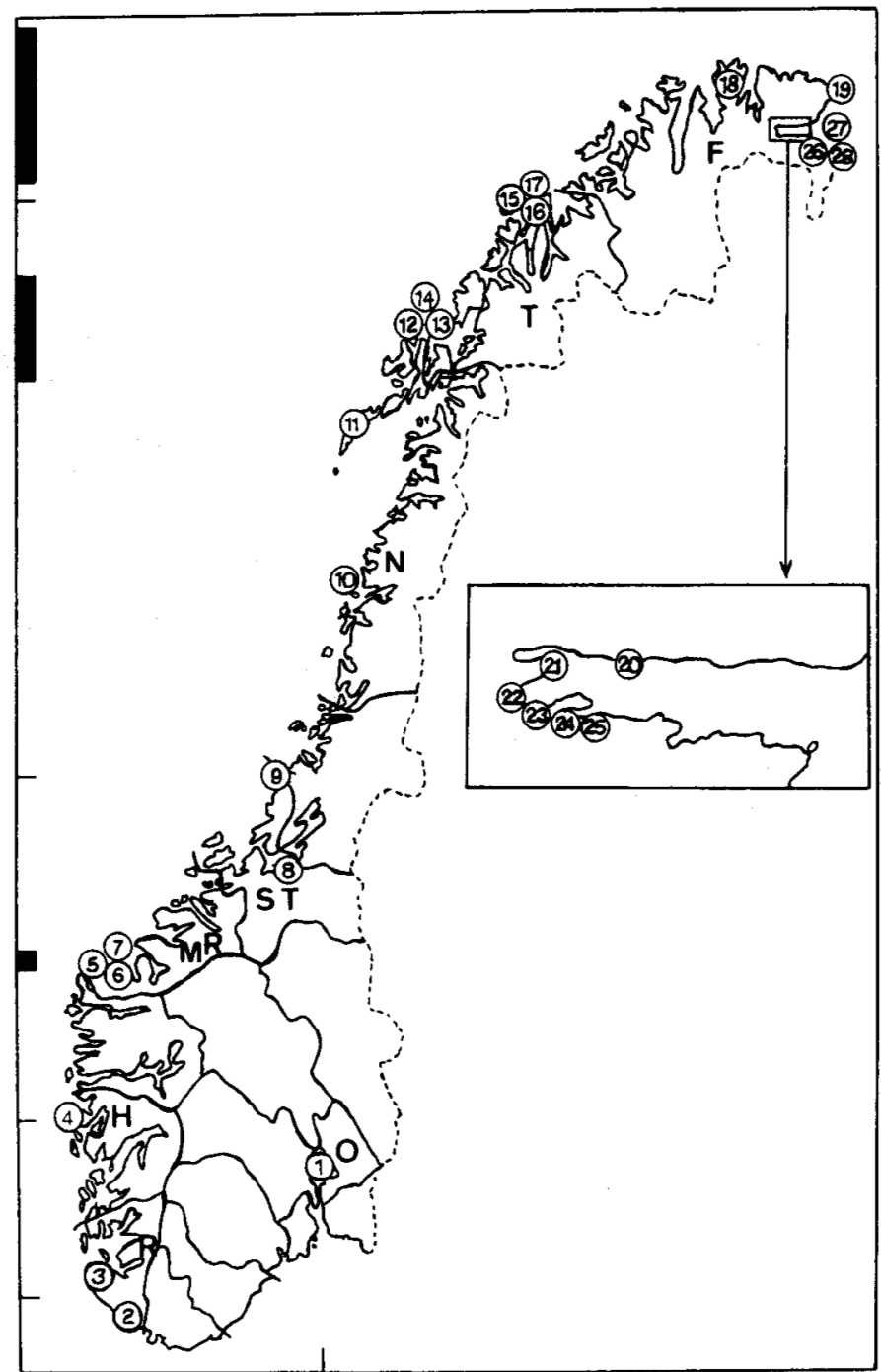

FIG. 2. Norwegian archaeological sites at which fulmar bones have been recovered. Numbers and letters correspond to locations and counties given in Table 2. Bars along border of figure are proportional to the percentages of bones uncovered at adjacent counties on map. Most of the known breeding population of fulmars in Norway is at Runde (Barrett and Vader, 1984), the site of the largest Norwegian colony of gannets.

$\left(x_{4}^{2}=127.4, P<0.001\right)$. Eighty percent of the fulmar bones were dated from 4000 to 1000 B.P., whereas $80 \%$ of the gannet specimens were dated from 6000 to 1000 B.P. (Fig. 3). The modal intervals of occurrence were 2000-1000 B.P. for fulmars (51\%) and $6000-5000$ B.P. (46\%) for gannets. There is no evidence to suggest differential survival of the bones of these different-sized species ( $R$. Lie, University of Bergen, pers. comm. 1988).

The bones of other avian species were dated from 9000 to 300 B.P. The temporal distribution of these bones tended to be more bimodal than those of the gannets and fulmars (Fig. 3) and was significantly different from each of them (for gannets $\mathrm{x}_{4}^{2}=41.12, \mathrm{P}<0.001$; for fulmars $\mathrm{x}_{4}^{2}=406.6, \mathrm{P}<0.001$ ). Fiftyeight percent $(4605 / 7968)$ of the bones of other avian species were recovered from sites dated <3000 B.P. and 37\% (2960/ 7968) between 7000 and 3000 B.P. (Fig. 3). There were no significant differences in the dates of sites in northern and
TABLE 3. Comparison of the numbers of archaeological sites at which gannet and fulmar bones have been collected and of gannet and fulmar bones collected in southern and northern Norwegian coastal regions

\begin{tabular}{lrrr}
\hline \hline & \multicolumn{2}{c}{ Gannet } & Fulmar \\
\hline & \multicolumn{3}{c}{ Sites } \\
\cline { 2 - 4 } Southern Norway & 17 & 9 \\
Northern Norway & 9 & 19 \\
& & $x_{1}^{2}=4.71, P<0.05$ \\
& \multicolumn{3}{c}{ Bones } \\
Southern Norway & \multicolumn{2}{c}{45} \\
Northern Norway & 49 & 551 \\
& \multicolumn{3}{c}{$x_{1}^{2}=203.3, P<0.01$} \\
\hline
\end{tabular}

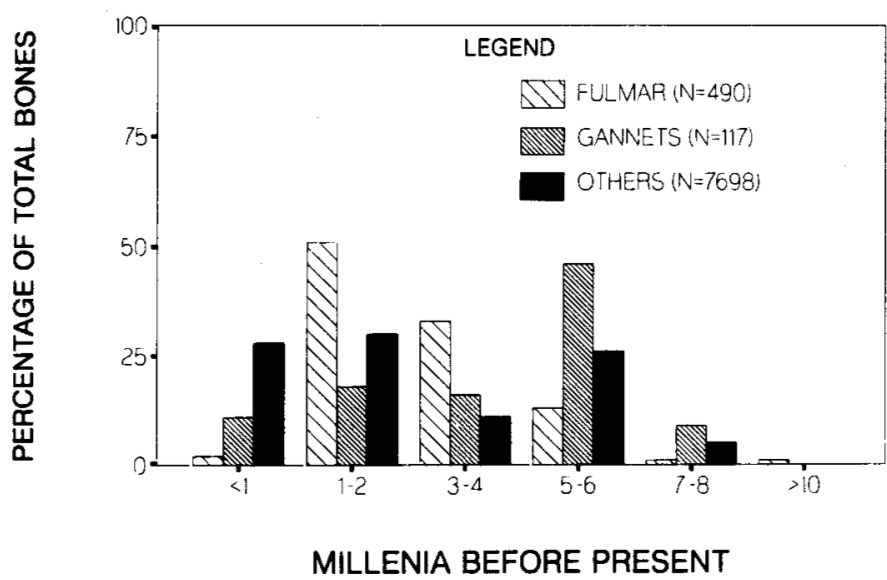

FIG. 3. Temporal distributions of the percentages of the total number of gannet and fulmar bones and those of other avian species recovered at Norwegian archaeological sites.

southern Norway at which bones of fulmars ( $F$ test; $P>0.05)$, gannets ( $\mathrm{F}$ test; $\mathrm{P}>0.05$ ) and other avian species (MannWhitney $U$ test; $P>0.05$ ) were recovered.

\section{DISCUSSION}

In view of current knowledge indicating that fulmars began breeding in Norway in the present century and that gannets did so within the past 50 years, it is informative to document that both species have occurred along the Norwegian coast for many millenia. In comparison to gannets and to other avian species, proportionally more of the fulmar material was obtained from proportionally more archaeological sites in northern Norway. Recent and present breeding distributions of fulmars are much more arctic in extent that those of boreal water gannets (Fisher, 1952; Nelson, 1978), and the geographic distribution of the specimens from Norwegian archaeological sites is consistent with a similar distribution in past millenia. In a somewhat related vein, specimens from coastal archaeological sites in eastern and western Canada suggest that avian species diversity in previous postglacial millenia is comparable to present species diversity (Montevecchi and Tuck, 1987; Hobson and Driver, 1989). Currently, the largest concentrations of breeding fulmars and gannets in Norway are located in the southern part of the country at Runde (Barrett and Vader, 1984; Montevecchi et al., 1987). 
Five times more fulmar bones than gannet bones were recovered. This difference is in the same direction as recent Norwegian breeding populations (Røv et al., 1984; Montevecchi et al., 1987) and seems consistent with present relative abundances of these species in Norwegian waters. Former relative abundance may have been similar, although interspecific differences in accessibility and/or the prey preferences of human hunters could have biased prehistoric ratios.

Temporal distributions of specimens suggest that gannets may have been more abundant along the Norwegian coast 5-6 millenia ago than in the more recent past. Fulmars, in turn, may have been more abundant 1-2 millenia ago than in the more distant or the more recent past. The temporal distributions of the gannet and of the fulmar bones are unlikely to be a simple reflection of human settlement patterns, as indicated by the differences between each of their temporal distributions and that of all other avian species collected at archaeological sites. The occurrence of gannets in Norwegian waters from approximately 7000 B.P. is consistent with warm climatological conditions (Cushing, 1982) and with their occurrence in Denmark at this time (M. Meldgaard, University of Copenhagen, pers. comm. 1989). Bengtson (1984) reported that Icelandic sagas indicated severe sea ice conditions along the Norwegian coast from the 13th through 17th centuries and suggested that these conditions may have significantly facilitated the great auks' extinction. Although great auks were likely gone from former Norwegian breeding sites well before this period (Hufthammer, 1982), such a climatological/oceanographic change would be consistent with a cessation of possible nesting by fulmars and gannets during these centuries (e.g., Barrett and Vader, 1984). There are few bones from fulmar and from other species during this period, although $13 \%(16 / 124)$ of the bones from gannets (primarily temperate and subarctic zone breeders) were from this period. More than two-thirds $(69 \%, 11 / 16)$ of the gannet bones, however, were from southern Norway, where oceanographic conditions were probably milder than more northerly ones and would have presumably supported the gannets' relatively warm-water pelagic prey (Kirkham et al., 1985; Montevecchi and Barrett, 1987).

Distributional studies of zooarchaeological material from other marine birds and mammals with different dietary and habitat preferences will lead to the generation of testable hypotheses about paleoecology and oceanography. The integration of these investigations with dietary reconstructions based on stable isotopic analyses of bone collagen (Hobson and Montevecchi, in prep.) will permit the testing of hypotheses about paleo-oceanographic food webs.

\section{ACKNOWLEDGEMENTS}

I. Byrkjedahl, L. Harris, President of Memorial University of Newfoundland, and B. Larsen provided valuable logistic support and encouragement. T. Fredriksen provided great assistance in cataloging avian species recovered at Norwegian archaeological sites, and D. Butler aided with statistical analyses, figure preparation and word processing. D.N. Nettleship, R.T. Barrett, G. Hodgson, I.R. Kirkham, M. Meldgaard and W. Vader made helpful comments on earlier versions of the manuscript. The collaboration that produced this contribution was a direct result of a Memorial University of Newfoundland - University of Bergen Exchange Program. Research was supported by an NSERC Individual Operating Grant (A0867).

\section{REFERENCES}

BARRETT, R.T., and VADER, W. 1984. The status and conservation of breeding seabirds in Norway. In: Croxall, J.P., Evans, P.G.H., and Schreiber, R.W., eds. Status and Conservation of the World's Seabirds. International Committee for Bird Protection Technical Publication 2:323-333.

BENGTSON, S.A. 1984. Breeding ecology and extinction of the great auk (Pinguinus impennis): anecdotal evidence and conjectures. Auk 101:1-12.

CUSHING, D.H. 1982. Climate and Fisheries. London: Academic Press. 373 p.

FISHER, J. 1952. The Fulmar. London: Collins. 496 p.

FRIEDMAN, H. 1934. Bird bones from Eskimo ruins on St. Lawrence Island, Bering Sea. Journal of the Washington Academy of Science 24:83-96.

GILBERT, B.M., MARTIN, L.D., and SAVAGE, H.G. 1981. Avian Osteology Laramie, Wyoming: Modern Printing. $252 \mathrm{p}$.

HALL, E.S., Jr. 1969. Avian remains from the Kangiguksuk site, northern Alaska. Condor 71:76-77.

HASEGAWA, H., and DeGANGE, A.R. 1982. The short-tailed albatross, Diomedea albatrus, its status, distribution and natural history. American Birds 36:806-814.

HELSKOG, K. 1980. The chronology of the younger stone age in Varanger, North Norway. Norwegian Archaeological Review 13:47-54.

HOBSON, K.A., and DRIVER, J.C. 1989. Archaeological evidence for use of the Straits of Georgia by marine birds. In: Vermeer, K., and Butler, R.W., eds. The Ecology and Status of Marine and Shoreline Birds in the Strait of Georgia, British Columbia. Special Publication, Canadian Wildlife Service, Ottawa. 168-174.

HOBSON, K.A., and MONTEVECCHI, W.A. In prep. Stable isotopic determination of the trophic status of the great auk.

HUFTHAMMER, A.K. 1982. Geirfuglens utbredelse og morfologiske variasjon i Skandinavia. Hovedfagsoppgave. Bergen, Norway: (Zoologisk okologi), Universitetet i Bergen. $60 \mathrm{p}$.

JORDAN, R.H., and OLSON, S.C. 1982. First record of the great auk (Pinguinus impennis) from Labrador. Auk 99:167-168.

KIRKHAM, I.R., McLAREN, P., and MONTEVECCHI, W.A. 1985. Foods and foraging patterns of gannets off eastern Newfoundland and Labrador. Canadian Journal of Zoology 61:1456-1463.

LARSEN, E., GULLIKSEN, S., LAURITSEN, S.-E., LIE, R., LOVLIE, R., and MANGERUD, J. 1987. Cave stratigraphy in western Norway; multiple Weichselian glaciations and interstadial vertebrate fauna. Boreas 16:267292.

LIE, R.W. 1990. Animal remains from a postglacial warm period in Norway. Fauna Norvegica, Series A 11: in press.

LUCAS, F.A. 1903. The great auk. Science 17:311-312.

MELDGAARD, M. 1988. The great auk, Pinguinus impennis (L.), in Greenland. Historical Biology 1:145-178.

MONTEVECCHI W.A., and BARRETT, R.T. 1987. Prey selection by gannets at breeding colonies in Norway. Ornis Scandinavica 18:319-322.

MONTEVECCHI, W.A., and TUCK, L.M. 1987. Newfoundland Birds: Exploitation, Study, Conservation. Cambridge: Nuttall Ornithological Club. $273 \mathrm{p}$.

MONTEVECCHI, W.A., BARRETT, R.T., RIKARDSEN, F., and STRANN, K.B. 1987. The population and reproductive status of gannets in Norway in 1985. Fauna Norvegica, Series C, Cinclus 10:65-72.

NELSON, J.B. 1978. The Gannet. Berkhamsted: Poyser. 336 p.

RØV, N., THOMASSEN, J., ANKER-NILSSEN, T., BARRETT, R.T., FOLKESTAD, A.O., and RUNDE, O. 1984. Sjofuglprosjktet, 1979-1984. Viltrapport 35. Trondheim: Universitetet i Trondheim. $109 \mathrm{p}$.

SCHLEDERMANN, P. 1980. Polynyas and prehistoric settlement patterns. Arctic 33:292-302.

SIEGEL, S. 1956. Nonparametric Statistics. New York: McGill-Hill.

SIMONSEN, P. 1974, 1975, 1980, 1982. Veidemenn paa Nordkalotten. Stensilserie B-historie 1,2,4,17. Inst. samfunnistenskap. Tromsø: University of Tromsø.

SKJøLSVOLD, A. 1977. Slettabøboplassen. Arkeologisk Museum i Stavanger. Skifter 2. $380 \mathrm{p}$.

SOLBERG, B. 1976. Jernalder paa Nordre Sunnmore. Bosetning, ressursutnyttelse og sosial struktur. Magistergrads avhandling, manus, Universitetet i Bergen, Bergen. $147 \mathrm{p}$.

VALEUR, P. 1947. Havhesten og havsula paa Runde. Naturen 70:370-379.

WALKER, P.L., and CRAIG, S. 1979. Archaeological evidence concerning the prehistoric occurrence of sea mammals at Point Bennett, San Miguel Island. California Fisheries and Game 65:50-54.

WINTEMBERG, W.J. 1919. Archaeology as an aid to zoology. Canadian Field-Naturalist 33:63-72.

YESNER, D.R. 1976. Aleutian Island albatrosses: a population history. Auk 93:263-280. 